Журнал «Герспективитаінноваціїнауки»

(Серія «Педагогіка», Серія «Гиихологія», Серія«Медицина»

№5(5) 2021

УДК 378.018.43.014.6-057.875-054.6

https://doi.org/10.52058/2786-4952-2021-5(5)-466-477

Малишевська Ольга Степанівна доктор біологічних наук, доцент, доцент кафедри гігієни та екології, Івано-Франківський національний медичний університет, вул. Галицька, 2, м. Івано-Франківськ, 76001, тел.: (096) 571-55-78, e-mail:o16r02@gmail.com, https://orcid.org/0000-0003-0180-2112

Тимощук Оксана Василівна доктор медичних наук, доцент, професор кафедри гігієни та екології, Івано-Франківський національний медичний університет, вул. Галицька, 2, м. Івано-Франківськ, 76001, тел.: (096) 163-529, e-mail: oksanavorob4ak@gmail.com, https://orcid.org/0000-0001-9179-9951

Мотрюк Віра Богданівна кандидат медичних наук, доцент, доцент кафедри педіатрії, Івано-Франківський національний медичний університет, вул. Галицька, 2, м. Івано-Франківськ, 76001, тел.: (099) 642-83-24, e-mail: vmotriyk@ifnmu.edu.ua, https://orcid.org/0000-0003-4347-8293

Суслик Зоряна Богданівна кандидат медичних наук, доцент кафедри гігієни та екології, Івано-Франківський національний медичний університет, вул. Галицька, 2, м. Івано-Франківськ, 76001, тел.: (095) 404-41-39, e-mail:zsuslik@ifnmu.edu.ua.

Погорілий Микола Петрович асистент кафедри гігієни та екології, ІваноФранківський національний медичний університет, вул. Галицька, 2, м. Івано-Франківськ, 76001, тел.: (068) 143-62-23, e-mail: mpohorilii@ifnmu.edu.ua, https://orcid.org/0000-0001-8664-8614

\title{
ПОРІВНЯННЯ ВПЛИВУ ДИСТАНЦИЙНОГО ТА ОЧНОГО НАВЧАННЯ НА СТУДЕНТІВ ВИЩИХ ТА ПЕРЕДВИЩИХ МЕДИЧНИХ НАВЧАЛЬНИХ ЗАКЛАДІВ
}

Анотація. Ситуація 3 поширенням COVID-19 періодично переводить навчальний процес у медичних вишах із очної у дистанційну форму. Однак, освітній процес у будь-яких формах навчання має відповідати всім гігієнічним вимогам та не викликати погіршення стану фізичного та психоемоційного здоров'я студентів.

Мета дослідження - вивчити вплив дистанційного навчання на стан фізичного та психічного здоров'я студентів медичних закладів.

Вивчення первинної захворюваності проводилося за медичними картами студентів. Дослідження показників індивідуального здоров'я вивчали через визначення показнику максимального споживання кисню, що характеризує 
резервні можливості організму. Психологічний мікроклімат оцінено шляхом анонімного анкетування студентів на через електронну платформу Google.

Встановлено, що рівень первинної захворюваності мав чітку тенденцію до погіршення за такими нозологічними формами захворювань: хвороби ока та його придаткового апарату, порушення постави, плоскостопість. Дані показники зросли від 1,27 до 2,54 рази ( $<0,01)$ після дворічного періодичного дистанційного навчання. Дослідженими встановлено тенденцію до ожиріння.

Оцінено індивідуальні показники здоров'я за допомогою функціональних спроб, що більшість студентів $(83,7 \%)$ мали середні чи задовільні рівні за винятком проби з присіданнями.

За результатами анкетування встановлено, що студенти: усвідомлювали складність у освоєнні навчального матеріалу $(94,2 \%$,) що пов'язане 3 дистанційним навчанням; відзначили збільшення тривалості сну та відпочинку (92,3 \%) та більш регулярне та повноцінне харчування $(90,2 \%)$, зазначили, що психологічний клімат був сприятливим для $58,2 \%$ респондентів, вказали на збільшення обсягу навчального навантаження (91,3\%), збільшення тривалості роботи 3 комп'ютером $(98,7 \%)$, зниження рухової активності $(93,2 \%)$, зменшення часу перебування на свіжому повітрі $(92,6 \%)$.

Погіршення свого здоров'я відзначили $86,7 \%$ респондентів, серед симптомів виділили: втому, відчуття печіння та сухості в очах, біль та відчуття оніміння в області шиї, біль у поперековій зоні хребта, головний біль, холодні кінцівки роздратованість, неможливість зосередитися, проблеми із запам'ятовуванням, часте бажання з'їсти щось солодке, апатія.

Дослідженнями встановлено, що у зв'язку із відсутністю стандартів, що регламентують навчально-виховний процес для дистанційної форми навчання для вищих навчальних закладів, лекційні та семінарські заняття не можуть тривати понад 3 місяці на рік за такої форми навчання.

Ключові слова: дистанційне навчання, онлайн навчання, вплив короновіруса на навчання студентів, наслідки COVID-19, вплив дистанційного навчання на здоров'я.

Malyshevska Olga Stepanivna Doctor of Biological Sciences, Associate Professor, Associate Professor of the Department of Hygiene and Ecology, National Medical University, Halytska St., 2, Ivano-Frankivsk, 76001, tel .: (096) 571-55-78, e-mail: o16r02@gmail.com, https://orcid.org/0000-0003-0180- 2112

Tymoschuk Oksana Vasylivna Doctor of Medical Sciences, Associate Professor, Professor of the Department of Hygiene and Ecology, National Medical University, Halytska St., 2, Ivano-Frankivsk, 76001, tel.: (099) 163-35-29, e-mail: oksanavorob4ak@gmail.com, https://orcid.org/0000-0001-9179-9951 
Motryuk Vira Bohdanivna Ph.D of Medical Sciences, Associate Professor, Associate Professor of the Department of Pediatrics, National Medical University, Halytska St., 2, Ivano-Frankivsk, 76001, tel: (099) 642-83-24, e-mail: vmotriyk@ifnmu.edu.ua, https://orcid.org/0000-0003-4347-8293

Suslyk Zoryana Bohdanivna Ph.D of Medical Sciences, Associate Professor of Hygiene and Ecology, National Medical University, Halytska St., 2, Ivano-Frankivsk, 76001, tel .: (095) 404-41-39, e-mail: zsuslik@ifnmu.edu.ua.

Pohoriliy Mykola Petrovych Assistant of the Department of Hygiene and Ecology, National Medical University, Halytska St., 2, Ivano-Frankivsk, 76001, tel.: (068) 143-62-23, e-mail: mpohorilii@ifnmu.edu.ua, https://orcid.org/0000-0001-8664-8614

\section{COMPARISON OF THE INFLUENCE OF DISTANCE AND FULL- TIME EDUCATION ON STUDENTS OF HIGHER AND ADVANCED MEDICAL EDUCATIONAL INSTITUTIONS}

Abstract. The situation with the spread of COVID-19 periodically shifts the educational process in medical universities from full-time to distance learning. However, the educational process in all forms of education must meet all hygienic requirements and not cause deterioration of physical and emotional health of students.

The aim of the study was to examine the impact of distance learning on the physical and mental health of medical students.

The study of primary morbidity was conducted on the medical records of students. Studies of individual health indicators were studied by determining the indicator of maximum oxygen consumption, which characterizes the body's reserve capacity. Detection of the psychological microclimate was conducted by anonymous questionnaires of students through the electronic platform Google.

It was found that the level of primary morbidity had a clear tendency to worsen in the following nosological forms of diseases: diseases of the eye and its appendages, posture disorders, flat feet. These indicators increased from 1.27 to 2.54 times ( $\mathrm{p}<0.01$ ) after two years of periodic distance learning. The researchers found a tendency to obesity.

Individual health indicators were assessed using functional trials, which the majority of students $(83.7 \%)$ had average or satisfactory levels except for the squat test.

According to the results of the questionnaire, it was found that students: were aware of the difficulty in mastering the educational material $(94.2 \%)$, which is associated with distance learning; noted an increase in the duration of sleep and rest (92.3\%) and more regular and complete nutrition (90.2\%), noted that the psychological climate was favorable for $58.2 \%$ of respondents, indicated an increase in workload $(91.3 \%)$ ), increase in duration of work with the computer $(98,7 \%)$, decrease in motor activity $(93,2 \%)$, decrease in time of stay in fresh air $(92,6 \%)$.

Deterioration of their health was noted by $86.7 \%$ of respondents, among the 
symptoms were: fatigue, burning and dry eyes, pain and numbness in the neck, lumbar spine pain, headache, cold extremities, irritability, inability to concentrate, problems with memorization, frequent desire to eat something sweet, apathy.

Research has shown that due to the lack of standards governing the educational process for distance learning for higher education, lectures and seminars can not last more than 3 months a year for this form of education.

Keywords: distance learning, online learning, the impact of coronavirus on student learning, the effects of COVID-19, the impact of distance learning on health.

Постановка проблеми. Нові освітні технології активно почали впроваджуватись В Україні останні п'ять-сім років. Це підвищило доступність до освітніх систем вищих навчальних закладів та $\epsilon$ особливо зручним за заочної та дистанційної форм навчання [1-3].

У зв'язку зі складною епідемічною ситуацією, викликаною росповсюдженням віруса COVID-19, що періодично переводить навчальний процес у медичних вишах із очної у дистанційну форму, особливу значущість набуває дистанційна форма навчання для очного освіти як вимушена міра. Однак, освітньо-навчальна система у будь-яких формах іiі навчання має відповідати всім гігієнічним вимогам та не сприяти погіршенню показників фізичного здоров'я та психоемоційного стану студентів [4-8]. Крім того, малорухливий спосіб життя, як результат зниження фізичного навантаження, призводить до зниження резервних можливостей організму [9-10].

Аналіз останніх досліджень і публікацій. Ізоляція, пов'язана 3 COVID-19, істотно вплинула на життя, навчання та функціональний стан студентів усіх вікових груп. Практично всі студенти раптово опинилися в ситуації різкої зміни традиційних форм занять в аудиторіях, зміни режиму та загального способу життя, зниження рухової активності та обмеження соціальних контактів. Кожен із цих факторів сам по собі є стресором, а їх поєднання разом із напруженими заняттями онлайн, створили ситуацію затяжного, токсичного стресу, наслідки якого можуть позначатися на здоров ’і та психосоціальній адаптації студентів протягом тривалого часу $[6,8]$. Аспекти дистанційного навчання в умовах ізоляції, вивчення яких проводилося науковцями в різних країнах світу, свідчить про загальні проблеми, що ускладнили, як організацію освітнього процесу, так й адаптацію студентів і викладачів до нової та несподіваної ситуації. Основними проблемами виділено: недостатня забезпеченість студентів i викладачів комунікативними пристроями та якісним інтернет-зв'язком, неналежна компетентності педагогів i студентів у цифрових технологіях $[1,4]$.

Слід зазначити, що прояви та наслідки затяжного стресу, що викликано ізоляцією в умовах COVID-19, лише почали аналізуватися і глибокий аналіз ще попереду, але вже є низка досліджень, які свідчать, що студенти з різних країн у процесі ізоляції відчували страх, тривогу, занепокоєння, втому [14]. Для 
глибокого та всебічного розуміння ситуації, що виникла, для прогнозування їі наслідків та розробки практичних рекомендацій необхідний аналіз організації режиму дня, умов та організації навчання студентів, оцінка їхнього функціонального стану в період ізоляції. Таке дослідження проведено науковцями кафедр гігієни та екології i педіатрії Івано-Франківського національного медичного університету інституту.

Мета дослідження - вивчити вплив дистанційного навчання на стан фізичного та психічного здоров'я студентів вищих та передвищих медичних закладів.

Матеріал та методи дослідження. Вивчення первинної захворюваності проводилося за медичними картами студентів за період iз 2016 по 2021 роки. Вивчено 11754 випадки захворювання (2016 р. - 1087; 2017 р. - 1394; 2018 р. 1253; 2019 р. - 2151; 2020 р. - 2743; 2021 р. (10 місяців) - 3126 відповідно). Студенти у 2016-2018 рр. навчалися за очною формою, а з березня 2019 по 2021 рр. перебували на дистанційному навчанні протягом від 3 до 5 місяців щорічно.

Для дослідження показників індивідуального здоров'я використовувалися тести навантаження, в основі яких лежить показник максимального споживання кисню (МСК), що характеризує резервні можливості організму: індекс Руф'є, проби Штанге, Генча, 3 присіданнями. Оцінка результатів проводилася за стандартною методикою вікового інтервалу від 15 до 19 років регламентованою Наказом МО3 України № 2205 від 25.09.20 року «Про затвердження Санітарного регламенту для закладів загальної середньої освіти» порушуючи «Вимоги до організації роботи з технічними засобами навчання».

Для характеристики варіаційного ряду при обчисленні досліджуваних тестів застосовувалися середня арифметична величина та середньоквадратичне відхилення $( \pm \delta)$.

При соціологічному опитуванні проводилося анкетування студентів, які перебували на дистанційному навчанні в період 2019-21 роках через електронний ресурс Google. Всього 4847 студентів, 3 них 71,3\% дівчат та 28,7 \% юнаків у віці від 15 до 19 років, 78,4 \% та 21,6 \% відповідно у віці від 20 до 23 років. Більшість із них (78,3 \%) анонімно відповіли на 23 запитання.

Виклад основного матеріалу. Рівень первинної захворюваності мав чітку тенденцію до погіршення за такими нозологічними формами захворювань: хвороби ока та його придаткового апарату, порушення постави, плоскостопість; причому у 2021 р. стосовно 2015 р. дані показники зросли від 1,27 до 2,54 рази $(\mathrm{p}<0,01)$. Дослідженими встановлено тенденцію до ожиріння, цей показник за досліджуваний період зріс у 2,54 рази $(\mathrm{p}<0,01)$ у дівчат та в 0,86 рази $(\mathrm{p}<0,01)$ у хлопців.

У той же час, незважаючи на зниження показників первинної захворюваності на хвороби органів травлення в 1,36 рази $(\mathrm{p}<0,01)$, зберігаються їх високі рівні. Кожен п’ятий студент має захворювання шлунково-кишкового тракту. Відзначається також зниження показників 
захворюваності органів дихання в 1,2 рази $(\mathrm{p}<0,01)$, що, швидше за все, пов'язане із зменшенням впливу застудного чинника. Значимість відмінностей інших нозологічних форм захворювань не суттєва (табл.1).

Протягом досліджуваного періоду структура захворюваності не змінилася: лідируючі позиції займали захворювання органів травлення, кістково-м'язової системи та сполучної тканини, хвороби нервової системи. Їхня сумарна питома вага становить понад 50 \% у будь-який рік із досліджуваного періоду.

Таблиия 1

Первинна захворюваність студентів на окремі захворювання в період від 2016 до 2021 року (із різними формами навчання)

\begin{tabular}{|c|c|c|c|c|c|c|}
\hline \multirow{2}{*}{ Види захворювань } & \multicolumn{5}{|c|}{ первинна захворюваність на 100 осіб } \\
\cline { 2 - 7 } & 2016 & 2017 & 2018 & 2019 & 2020 & 2021 \\
\cline { 2 - 7 } & \multicolumn{5}{|c|}{ форма навчання } \\
\cline { 2 - 7 } & \multicolumn{5}{|c|}{ очная } & \multicolumn{3}{|c|}{ дистанційна } \\
\hline Гострі респіраторні захворювання & 7,3 & 7,9 & 9,0 & 8,3 & 8,9 & 11,7 \\
\hline Риніти, хронічні фарингіти, синусити & 5,1 & 5,4 & 4,7 & 4,6 & 4,2 & 4,9 \\
\hline Гастрити, дуоденіти, функціональні розлади \\
шлунка
\end{tabular}

Дистанційна форма навчання передбачає зниження рухової активності, отже фізичної підготовленості студентів.

Для оцінки фізіологічних змін, які відбуваються внаслідок зниження рухової активності нами оцінено індивідуальні показники здоров'я за допомогою функціональних спроб. Оцінка навантажувальних тестів показала, що більшість студентів $(83,7 \%)$ мали середні чи задовільні рівні за винятком проби з присіданнями. Крім того, показники за період із 2019 до 2021 років під час дистанційного формату навчання були гіршими, ніж аналогічні показники за період із 2016 до 2018 років.

Проба з присіданнями є найпростішим способом оцінки резервів здоров'я та, як правило, не використовується окремо. Але лише з оцінкою інших індексі та величин, що відповідають за загальний стан здоров'я індивіда (табл.2). 
Журнал «Герспективитаінноваціїнауки»

(Серія «Педагогіка», Серія «Гиихологія», Серія«Медицина»

№5(5) 2021

Таблиия 2

Оцінка навантажувальних тестів, виконаних студентами за період від 2016 до 2021 року (із різними формами навчання)

\begin{tabular}{|c|r|r|r|r|r|r|}
\hline \multirow{2}{*}{ Навантажувальні тести } & 2016 & 2017 & 2018 & 2019 & 2020 & 2021 \\
\cline { 2 - 7 } & \multicolumn{3}{|c|}{ очна } & \multicolumn{3}{|c|}{ дистанційна } \\
\hline Індекс Руф'є (показник) & $6,2 \pm 1,8$ & $6,3 \pm 1,4$ & $7,0 \pm 1,8$ & $7,5 \pm 1,7$ & $8,1 \pm 1,9$ & $8,6 \pm 1,7$ \\
\hline $\begin{array}{c}\text { Проба із } \\
\text { присіданнями (\%) }\end{array}$ & 31,7 & 32,3 & 35,8 & 45,1 & 40,7 & 44,8 \\
\hline Проба Штанге (сек.) & $64,3 \pm 1,8$ & $62,3 \pm 2,1$ & $59,8 \pm 1,9$ & $52,4 \pm 2,0$ & $50,6 \pm 2,4$ & $48,2 \pm 2,2$ \\
\hline Проба Генча (сек.) & $41,2 \pm 2,8$ & $39,7 \pm 2,0$ & $38,4 \pm 2,6$ & $32,1 \pm 1,8$ & $30,8 \pm 2,2$ & $28,4 \pm 2,1$ \\
\hline
\end{tabular}

За результатами анкетування встановлено, що всі студенти (100 \%) мали гаджети (смартфони, планшети, ноутбуки, персональні комп'ютери) за допомогою яких навчалися. Серед опитаних студентів: 2,2 \% мали обмежений час доступу до мережі Інтернет; 94,2 \% усвідомлювали складність у освоєнні навчального матеріалу, що пов'язане 3 дистанційним навчанням; 5,2 \% не змогли адаптуватися до навчання в даному форматі і були або відраховані, або скеровані в академічну відпустку; 5,4 \% вважають що форма навчання не вплинула на якість одержаних ними знань.

Як позитивний момент дистанційного навчання більшість студентів відзначили збільшення тривалості сну та відпочинку $(92,3 \%)$, більш регулярне та повноцінне харчування $(90,2 \%)$, знизилися витрати на транспорт у 98,5\%, на проживання у гуртожитку та зйомних квартирах (90,1\% від проживаючих не у власних помешканнях), психологічний клімат був сприятливим для $58,2 \%$ респондентів, із родиною стали кращими взаємовідносини в 73,4\%, був прямий зв'язок 3 викладачем $(98,7 \%)$, навчально-методичним забезпеченням дисциплін, яке виставлено на сайтах навчальних кафедр, його доступністю та повнотою було задоволено 64,3\%.

Анкетуванням виявлено і ряд негативних факторів впливу дистанційного навчання на студентів. Зокрема студентами виділено: відсутність окремої кімнати для занять $(22,4 \%)$, збільшення обсягу навчального навантаження $(91,3 \%)$, збільшення тривалості роботи 3 комп'ютером $(98,7$ \%), зниження рухової активності (93,2 \%), зменшення часу перебування на свіжому повітрі $(92,6 \%)$ (рис. 1).

Погіршення свого здоров'я відзначили $86,7 \%$ респондентів, серед симптомів виділили: втому, відчуття печіння та сухості в очах, біль та відчуття оніміння в області шиї, біль у поперековій зоні хребта, головний біль, холодні кінцівки (рис. 2), роздратованість, неможливість зосередитися, проблеми із запам'ятовуванням, часте бажання з'їсти щось солодке, апатія (рис. 3). 


\section{об'єктивні причини негативного впливу COVID-19 на навчання студентів, (\%)}

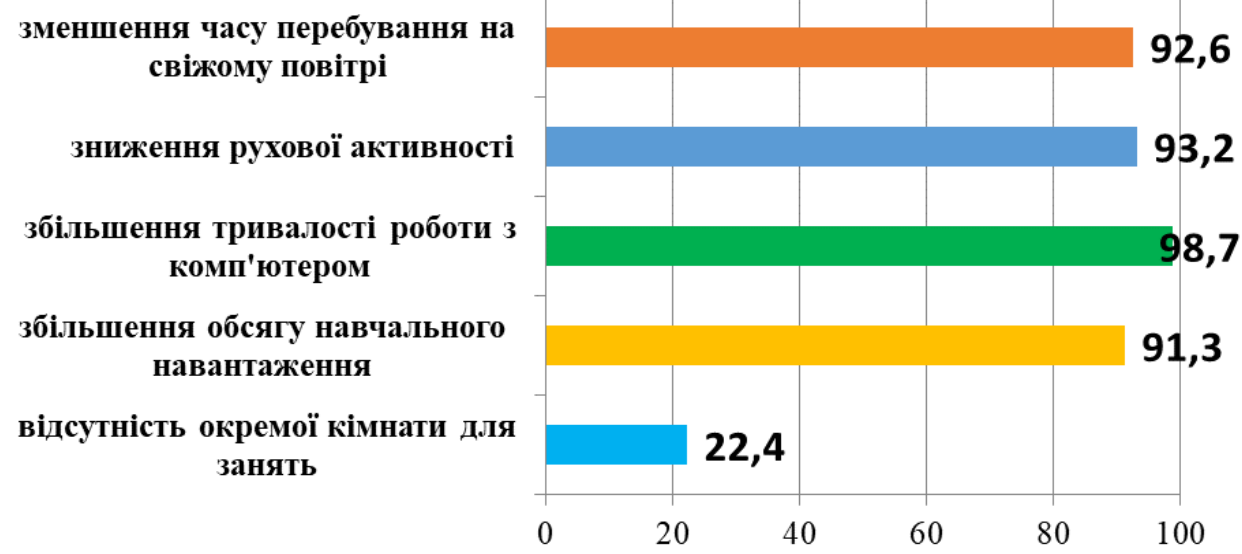

Puc. 1. Виявлення об'єктивних причин негативного впливу дистанційного навчання на студентів в умовах COVID-19

\section{оцінка суб'єктивного впливу дистанційного} навчання на фізичне здоровя студентів, (\%)

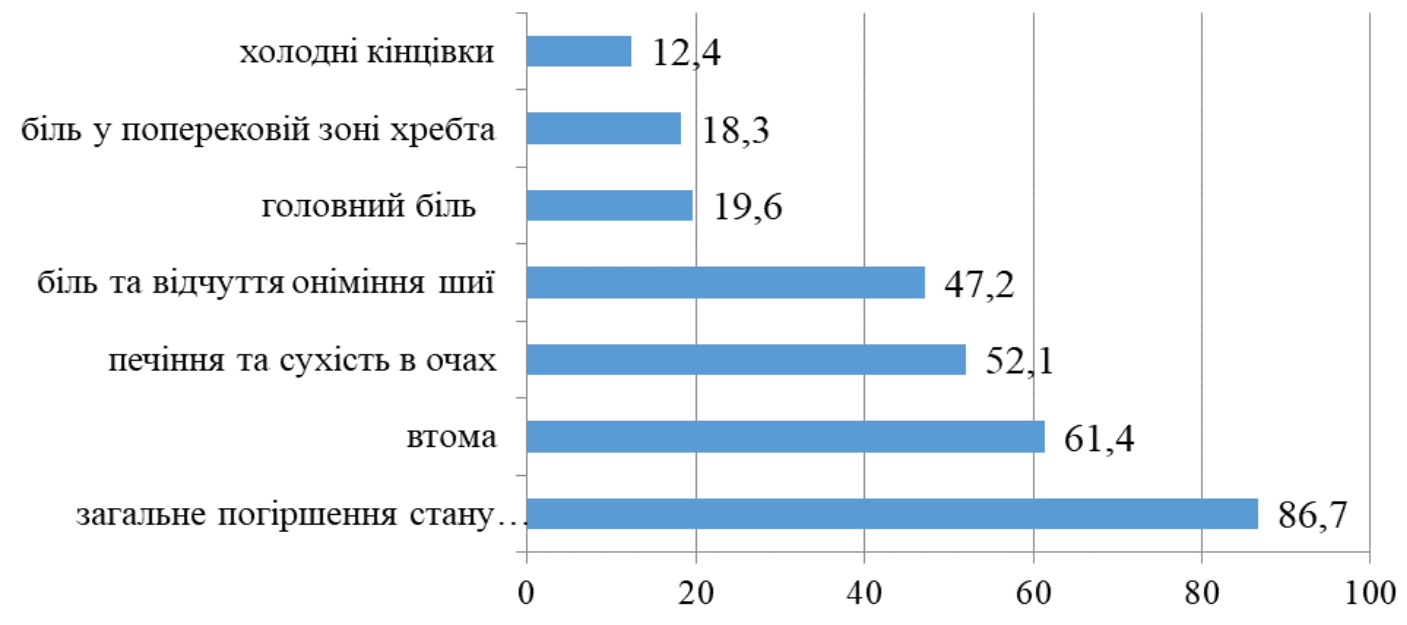

Pис. 2. Виявлення суб'єктивних причин негативного впливу дистаниійного навчання на фізичне здоров'я студентів в умовах COVID-19

Сприйняття навчального матеріалу було задовільним для 47,6 \%, добрим $-43,2 \%$, відмінним - 9,6\% серед проанкетованих. Збільшення обсягу завдань та часу на їх виконання, на думку $98,2 \%$ опитаних зменшило час перерви між заняттями, що не дозволяло повноцінно відпочити між заняттями.

Окремо слід зазначити, що результати успішності студентів сесійного заліково-екзаменаційного контролю, котрі були проаналізовані за період від 2016 до 2021 років суттєво не відрізнялися за очної та дистанційної формах навчання. Третій та четвертий рівні (високі) мали 93,8 \% та 98,4 \% студентів відповідно (середні значення сесійного контролю з 2016 по 2019 та 2020/2021) 
Журнал«Герспективитаінновації науки

(Серія«Гедагогіка»), Серія«ГТихологія», Серія «Медицина»

№5(5) 2021

що пов'язано, як правило, з високою майстерністю та досвідом професорськовикладацького складу університету.

\section{оцінка суб'єктивного впливу дистанційного навчання на психічне здоровя студентів, (\%)}

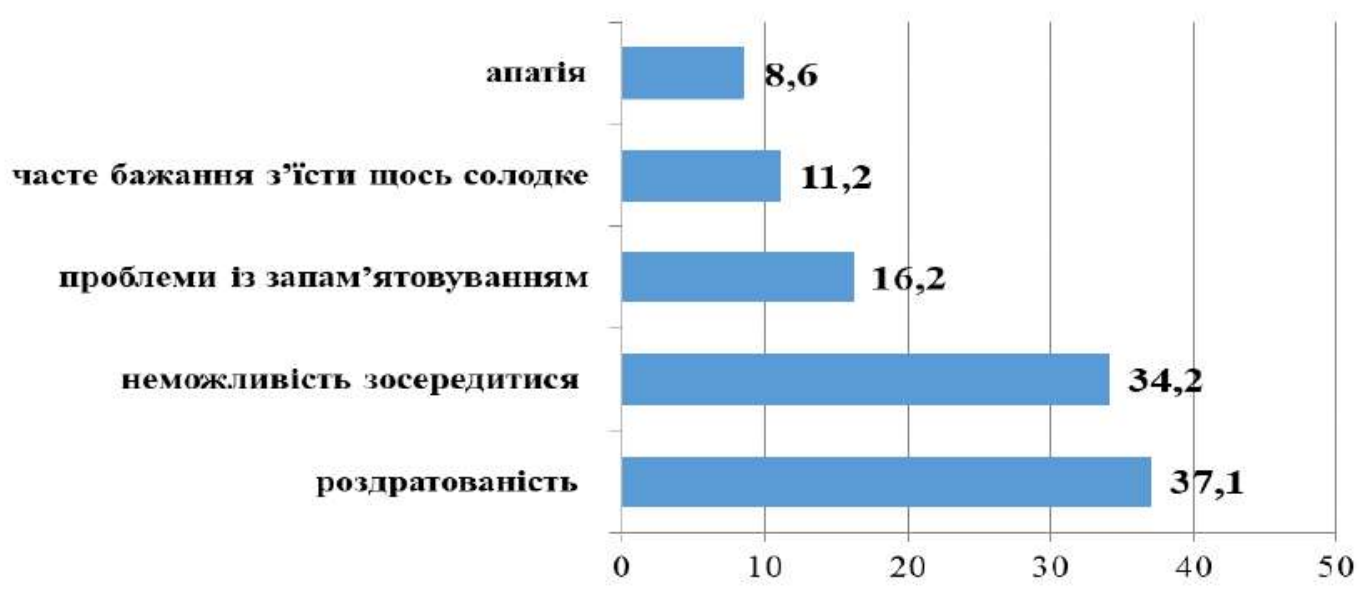

Pис. 3. Виявлення суб'єктивних причин негативного впливу дистанційного навчання на психологічне здоров'я студентів в умовах COVID-19

Обговорення. Існуючі умови дистанційного навчання, що супроводжують навчально-виховний процес в онлайн-форматі, не відповідають основним санітарно-гігієнічним вимогам регламентованих Наказом МO3 України № 2205 від 25.09.20 року «Про затвердження Санітарного регламенту для закладів загальної середньої освіти» порушуючи «Вимоги до організації роботи 3 технічними засобами навчання». Зокрема порушено вимогу безперервної тривалість навчальної діяльності з технічними засобами навчання упродовж навчального заняття, що повинна не перевищувати на 1-й годині занять до 30 хвилин, на 2-й годині занять - 20 хвилин. При здвоєних навчальних заняттях - не більше 25-30 хвилин на першому навчальному занятті та не більше 15-20 хвилин на другому. Реальна тривалість роботи студентів із використанням технічних засобів навчання триває від 6 до 10 годин щодня.

Тривала робота на комп'ютері до 10 годин на день протягом 6 днів не може не позначитися на погіршенні здоров'я студентів, що підтверджується об'єктивними даними: зростанням первинної захворюваності на кістковом'язову систему, пов'язану з статистичною втомою від постійного перебування у фіксованій позі, захворюванням очей, як результатом зорової втоми від роботи перед монітором гаджета, проявами накопичення зайвої ваги, що виникає при малорухливому способі життя, зниженням фізичної підготовки студентів та задовільною, на противагу гарній реакції відновлення організму після навантаження, як це було при очній формі навчання.

Ці тенденції підтверджуються i соціологічним опитуванням серед студентів та проведеними дослідженнями інших науковців $[3,8-11,15]$. 
Привертає увагу те, що втрати здоров'я формуються за досить короткий період часу.

Висновки. Погіршення, як фізичного так i психічного самопочуття студентів вищих і передвищих навчальних закладів під час дистанційного навчання зумовлене різким зменшенням їх рухової активності, що вилилось у зростанні первинної захворюваності на кістково-м'язову систему, тенденцією до ожиріння; низькими (задовільними) показниками відновлення організму після виконання тестів навантаження. Крім цього, тривале перебування перед монітором цифрових пристроїв негативно позначилось на гостроті зору, а також спровокувало підвищення рівня захворюваності на хвороби ока та його придаткового апарату.

За результатами проведеного анкетування та аналізом матеріалів досліджень інших науковці встановлено, що основними факторами ризику, котрі можуть негативно вплинути на організм студентів, стало збільшення тривалості роботи з цифровими пристроями, зниження рухової активності, обмежена можливість виконання коригувальних фізичних вправ.

Дослідженнями встановлено, що у зв'язку із відсутністю стандартів, що регламентують навчально-виховний процес для дистанційної форми навчання для вищих навчальних закладів, лекційні та семінарські заняття не можуть тривати понад 3 місяці на рік за такої форми навчання.

\section{Jimepamypa:}

1. Hantem A.. Les conditions de l'enseignement à distance pendant le confinement dû au COVID-19: Cas de l'enseignement supérieur au Maroc. [Internet]. 2020 [cited 2021 Dec 02]. Available from: https://hal.archives-ouvertes.fr/hal-02883214.

2. S. El Firdoussi, M. Lachgar, H. Kabaili, A. Rochdi, D. Goujdami, and L. El Firdoussi, "Assessing distance learning in higher education during the COVID-19 pandemic," Education Research International, vol. 13, 2020.

3. M. Al-Balas, H. I. Al-Balas, H. M. Jaber et al., "Distance learning in clinical medical education amid COVID-19 pandemic in Jordan: current situation, challenges, and perspectives," BMC Medical Education, vol. 20, no. 1, p. 341, 2020.

4. J. G. Ruiz, M. J. Mintzer, and R. M. Leipzig, "The impact of E-learning in medical education," Academic Medicine, vol. 81, no. 3, pp. 207-212, 2006.

5. N. Mehta, C. Sayed, R. Sharma, and V. Do, "Medical education advances and innovations: a silver lining during the COVID-19 pandemic," Canadian Med. Educat. J, vol. 11, 2020.

6. L. P. Howell, J. P. Joad, E. Callahan, G. Servis, and A. C. Bonham, "Generational forecasting in academic medicine: a unique method of planning for success in the next two decades," Academic Medicine, vol. 84, no. 8, pp. 985-993, 2009.

7. D. O’Doherty, M. Dromey, J. Lougheed, A. Hannigan, J. Last, and D. McGrath, "Barriers and solutions to online learning in medical education - an integrative review," BMC Medical Education, vol. 18, no. 1, p. 130, 2018.

8. L. Pei and $\mathrm{H}$. Wu, "Does online learning work better than offline learning in undergraduate medical education? A systematic review and meta-analysis," Medical Education Online, vol. 24, no. 1, Article ID 1666538, 2019.

9. A. K. Bolatov, T. Z. Seisembekov, A. Z. Askarova, R. K. Baikanova, D. S. Smailova, and E. Fabbro, "Online-learning due to COVID-19 improved mental health among medical students," Medical Science Educator, vol. 31, pp. 1-10, 2020. 
10. Y. Sandhaus, T. Kushnir, and S. Ashkenazi, "Electronic distance learning of pre-clinical studies during the COVID-19 pandemic: a preliminary study of medical student responses and potential future impact," Israel Medical Association Journal, vol. 8, no. 22, pp. 423-427, 2020.

11. S.-Q. Wang and F.-Y. Xu, "Letter to the editor regarding "the evolving impact of covid19 on medical student orthopedic education: perspectives from medical students in different phases of the curriculum," Geriatric Orthopaedic Surgery \& Rehabilitation, vol. 11, 2021.

12. Plateforme de formation-Faculté de Médecine et de Pharmacie de Marrakech [Internet]. Available from: http://www.fmpm.uca.ma/?page_id=374.

13. N. K. Ibrahim, R. Al Raddadi, M. AlDarmasi et al., "Medical students' acceptance and perceptions of e-learning during the Covid-19 closure time in King Abdulaziz University," Journal of Infection and Public Health, vol. 14, no. 1, 2020.

14. S. Nepal, A. Atreya, R. G. Menezes, and R. R. Joshi, "Students' perspective on online medical education amidst the COVID-19 pandemic in Nepal," Journal of Nepal Health Research Council, vol. 18, no. 3, pp. 551-555, 2020. T. Loda, T. Löffler, R. Erschens, S. Zipfel, and A. Herrmann-Werner, "Medical education in times of COVID-19: German students' expectations - a cross-sectional study," PloS One, vol. 15, no. 11, Article ID e0241660, 2020.

15. S. Dost, A. Hossain, M. Shehab, A. Abdelwahed, and L. Al-Nusair, "Perceptions of medical students towards online teaching during the covid-19 pandemic: a national cross-sectional survey of 2721 UK medical students," BMJ Open, vol. 10, no. 11, 2020.

\section{References:}

1. Hantem A.. Les conditions de l'enseignement à distance pendant le confinement dû au COVID-19: Cas de l'enseignement supérieur au Maroc. [Internet]. 2020 [cited 2021 Dec 02]. Available from: https://hal.archives-ouvertes.fr/hal-02883214.

2. S. El Firdoussi, M. Lachgar, H. Kabaili, A. Rochdi, D. Goujdami, and L. El Firdoussi, "Assessing distance learning in higher education during the COVID-19 pandemic," Education Research International, vol. 13, 2020.

3. M. Al-Balas, H. I. Al-Balas, H. M. Jaber et al., "Distance learning in clinical medical education amid COVID-19 pandemic in Jordan: current situation, challenges, and perspectives," BMC Medical Education, vol. 20, no. 1, p. 341, 2020.

4. J. G. Ruiz, M. J. Mintzer, and R. M. Leipzig, "The impact of E-learning in medical education," Academic Medicine, vol. 81, no. 3, pp. 207-212, 2006.

5. N. Mehta, C. Sayed, R. Sharma, and V. Do, "Medical education advances and innovations: a silver lining during the COVID-19 pandemic," Canadian Med. Educat. J, vol. 11, 2020.

6. L. P. Howell, J. P. Joad, E. Callahan, G. Servis, and A. C. Bonham, "Generational forecasting in academic medicine: a unique method of planning for success in the next two decades," Academic Medicine, vol. 84, no. 8, pp. 985-993, 2009.

7. D. O’Doherty, M. Dromey, J. Lougheed, A. Hannigan, J. Last, and D. McGrath, "Barriers and solutions to online learning in medical education - an integrative review," BMC Medical Education, vol. 18, no. 1, p. 130, 2018.

8. L. Pei and H. Wu, "Does online learning work better than offline learning in undergraduate medical education? A systematic review and meta-analysis," Medical Education Online, vol. 24, no. 1, Article ID 1666538, 2019.

9. A. K. Bolatov, T. Z. Seisembekov, A. Z. Askarova, R. K. Baikanova, D. S. Smailova, and E. Fabbro, "Online-learning due to COVID-19 improved mental health among medical students," Medical Science Educator, vol. 31, pp. 1-10, 2020.

10. Y. Sandhaus, T. Kushnir, and S. Ashkenazi, "Electronic distance learning of pre-clinical studies during the COVID-19 pandemic: a preliminary study of medical student responses and potential future impact," Israel Medical Association Journal, vol. 8, no. 22, pp. 423-427, 2020. 
11. S.-Q. Wang and F.-Y. Xu, "Letter to the editor regarding "the evolving impact of covid19 on medical student orthopedic education: perspectives from medical students in different phases of the curriculum," Geriatric Orthopaedic Surgery \& Rehabilitation, vol. 11, 2021.

12. Plateforme de formation-Faculté de Médecine et de Pharmacie de Marrakech [Internet]. Available from: http://www.fmpm.uca.ma/?page_id=374.

13. N. K. Ibrahim, R. Al Raddadi, M. AlDarmasi et al., "Medical students' acceptance and perceptions of e-learning during the Covid-19 closure time in King Abdulaziz University," Journal of Infection and Public Health, vol. 14, no. 1, 2020.

14. S. Nepal, A. Atreya, R. G. Menezes, and R. R. Joshi, "Students' perspective on online medical education amidst the COVID-19 pandemic in Nepal," Journal of Nepal Health Research Council, vol. 18, no. 3, pp. 551-555, 2020. T. Loda, T. Löffler, R. Erschens, S. Zipfel, and A. Herrmann-Werner, "Medical education in times of COVID-19: German students' expectations a cross-sectional study," PloS One, vol. 15, no. 11, 2020.

15. S. Dost, A. Hossain, M. Shehab, A. Abdelwahed, and L. Al-Nusair, "Perceptions of medical students towards online teaching during the covid-19 pandemic: a national cross-sectional survey of 2721 UK medical students," BMJ Open, vol. 10, no. 11, 2020. 